\title{
THE BASIS FOR A LEARNING VIEW - EDUCATION, EXPERIENCE AND PRACTICE
}

\author{
Joar Sande \\ Western Norway University of Applied Sciences \\ Department of Computer science, Electrical engineering and Mathematical sciences (Norway)
}

\begin{abstract}
This article tells about my own experiences as a student and professor in technical education in Norway and USA in the 1980s and 90s, and economic education in Norway the academic year 2000-01. In technical education in Norway in the 1980s it was not necessary to put that much effort into your studies get a good grade. In the United States, on the other hand, students had two work hard to keep up to get good results. Norwegian higher education, however, has become more like American higher education after the Bologna process. A fresh university professor is nothing more than an advanced student, in the beginning one sticks to the textbook, and any deviation from the plan can cause light panic. As time goes by, the professor gains experience and growing self-confidence, and can start to experiment. My journey in teaching control engineering ended up with flipped classroom, based upon sociocultural learning, where both students and professors participate with the knowledge they have. Learning happens best if people interact and construct new knowledge together. The participants in the learning environment extend their closest (proximal) development zone by collaborating with others.
\end{abstract}

Keywords: Technical education, blended learning, flipped classroom, sociocultural learning, control engineering.

\section{Introduction}

-You are going to be a doctor, my grandmother told me. She said I had to bow to the medical secretary when I was at the doctor's office to get prescriptions for her. The medical secretary was the wife of the doctor. I did not bow, of course, because no one else did. Doctors were some of the finest grandma knew. There are many with higher education in my family for generations back, but no doctors. My conclusion was that there was one thing I should not become, and it was a doctor. I did not listen much to Grandma. The experiences I have from my own education have shaped me as a teacher. The teachers I have had have laid the foundation for my own educational and didactic approach to learning. Good, but also those perceived as bad teachers, have an approach to teaching that can be learned from. This article has two parts: In the first, I look at my own experiences as a student. The second section deals with my learning view, based on the subject area of control engineering which I have taught for over 20 years.

\section{Own experiences as a student}

After high school, I was in the Navy for one year, before I started at Bergen Engineering College in 1986, getting an engineering degree in automation technology. After that, I went on to the US for a 6-years master's degree in Electrical Engineering. I was dean of the Engineering Department at Sogn og Fjordane University College (SFIH) in the period from 1996 to 2000, and in my sabbatical leave after that, I pursued a degree in business economics at BI Norwegian Business School in Bergen the academic year 2000-01.

\subsection{Bergen college of engineering 1986-1989}

Bergen College of Engineering $(\mathrm{BIH})$ was one of the largest engineering education schools in Norway in the 1980 s, with traditions dating back to 1875 . The school, run by the county council, was taken over by the state and became a university college in 1977. The engineering programs went from being two-year to three-year in the early 80s. It was set up for teaching as in high school, with teaching in classrooms with the same schedule every week. The teachers did not have a common educational 
platform; they taught in their own way and had the same courses every year. There were assignments and laboratory exercises, but there were no particularly high demands on the students. The mathematics teacher took the students to the blackboard to show their calculations to the class, which meant that the students had to be well prepared for the lessons. The results in mathematics were therefore good. In some courses there were part-time professors, who came and did the job and not more than that. In any case, the students did not have the habit of visiting the professors at the office to ask for help. There were few and low requirements for the students, it was enough to read 14 days before the exam to get a decent grade. There were only written exams, usually of 5 hours, as final assessment. In one course we had a presentation, the only time we had to present something oral to the class. Most of the students probably had a feeling that they could not do anything practical after the education had finished, there were no subjects where we had gone into depth. This was the case in all engineering education in Norway in the 1980s and 1990s, the curriculum had many small courses that covered many different topics. The feeling was that no one was "good" in anything, but a foundation was laid anyway. If one was to study further and take a master's degree, it was the Norwegian Institute of Technology in Trondheim and the South Dakota School of Mines and Technology (SDSM\&T) in Rapid City, USA, which were the most relevant universities. BIH had a cooperation agreement with SDSM\&T, the course fit was approved beforehand, and therefore many went that way. Some went on to the Department of Physics at the University of Bergen (UiB), which offered a master's degree in physics.

\subsection{South Dakota school of mines and technology 1989-1992}

In American higher education there were many elements in the final assessment; assignments, laboratory exercises, tests, quizzes, and exams. This meant that the students had to work at a steady pace to keep up. You could typically achieve a final score of 700 points, where assignments and laboratory exercises counted 100 points each, tests 200 points, quizzes 100 points and the final exam 200 points. There were many oral presentations for the class, in the Senior Design Project there were five short reports with oral presentations underway, and a demonstration of the finished product in the end. Communication subjects and historical subjects were electives, and some were compulsory. To a small extent, there were project work where the students had to work in teams. We who came from Norway were used to working in teams and had more practical experience than the American students had. John Dewey's ideas on "learning by doing ", with a lot of group and project work, never really broke through in the United States (Dewey, 1962). The students from Asia were strong theoretical in mathematics and physics, but far less strong in practical subjects. Those from China, as an example, had just programmed on paper, without testing their programs on a computer.

A study at American universities in 1987 (Chickering \& Gamson, 1987) found that there were seven important factors that could help improve teaching. These seven factors are contact between students and professors, developing reciprocity and collaboration between students, using active learning techniques, providing quick feedback, emphasizes time on task, communicating high expectations and taking care of different talents and ways of learning.

Our education from Norway stood out well, compared to the education from other countries. The biggest difference was that we as students were "forced" to work hard, and it produced good results. It was also a short distance to the professor's office to ask for help. The students could enter a contract with the professor, one could choose to work towards an A and then receive clear feedback on what was expected. Otherwise, it was lessons in small classes, in some cases it went so fast that it seemed like the goal was to fill as many boards as possible in one class time. This meant that it was only time to write it down, and that the notes had to be reviewed afterwards. There was a lot of problem solving as homework, where emphasis was on repetition with solving many similar problems, until everyone understood the material. The exams were often multiple-choice, but those who already had a good A did not have to take it. The professor finally weighted the results after some sort of normal distribution, so that it was enough A and B. They decided everything that had to do with their courses. However, the department head gave clear notice if the grades were too bad. - I do not care what you do, but grades will have to be better!

\subsection{Norwegian business school $2000-2001$}

The first year at BI Norwegian Business School was the same for all fields of study, with lectures in large auditoriums with up to 300 students. Not all the material was reviewed, the lectures were mostly a guide on whether you succeeded in progression. The student group was composed of those coming from high school and adults who took further education or were on retraining. It was one group home exam, but there was no project work beyond that. There were no oral presentations, which can be difficult to have with such large student groups. The program worked well for them with a background from working life but made great demands on self-discipline. The students themselves had to make sure that they succeeded, and those who came straight from high school could easily fall out of the system. 
The biggest difference from technical education was that everything here centered on economy and economic returns. In a course, a spreadsheet should be prepared in connection with an analysis in accounting. You should make this spreadsheet yourself, but you could purchase it. One student had found a way to make money. It seemed legitimate to do so. The examination marks in the various courses were also weighted here, so that there was a normal distribution.

\subsection{The Bologna process}

The Bologna Process (Dahl \& Lindberg-Sand, 2009; Gornitzka, 2007), with the introduction of 3-year bachelor's degrees and 5-year master's degrees followed by 3-years doctoral degrees, has made Norwegian and European graduate education more like American graduate education. Globalization has meant that there are no longer national borders when it comes to education, and education must be comparable. The Quality Reform in Norway, which was introduced in the academic year 2003-04 (Fägerlind \& Strömqvist, 2004), made it possible to depart from the written examination as the only assessment element. It opened for so-called folder assessment, which can include tests and other student work. Closer follow-up of the students should prevent dropout.

\section{Control engineering}

\subsection{Introduction}

My learning view is essentially based on the sociocultural learning view, learning happens best if people interact and construct new knowledge together (Dysthe, 1999). The participants in the learning environment extend their closest (proximal) development zone (Vygotsky, 1978) by collaborating with others. The single student is a participant on par with everyone else, where everyone is equally important with the expertise and knowledge they have.

\subsection{Change of teaching program}

Professors plan forms of teaching they master, and students use learning strategies they are comfortable with. This can cause both parties to do more of what does not work. A new professor, newly graduated or experienced in the field of practice, needs to hang on to the teaching. In the beginning, it is a survival strategy, a bit in the same way as for fresh students. You must be confident about yourself, your colleagues and your students before you can give good teaching. Is there an introduction to the educational mindset of the university, and a common platform? It is difficult to organize the learning in any other way that is usual in the university. In the first year, notes or memorized content governs the teaching sessions. It is difficult to find room for activities that deviate from the planned arrangement.

I taught my first year as a professor at SFIH control engineering, also called technical cybernetics, which deals with automatic control of physical parameters such as speed, position, and temperature. Earlier subjects in mathematics and physics is the base. The program I followed was the textbook, traditionally laid out with theory teaching, computational exercises, and laboratory exercises. I did not have any educational education, and I made a program that I was used to as a student, and that was like my colleagues' plans. Control engineering was then two courses, Control Engineering 1 ( 6 credit points) and Control Engineering 2 ( 9 credit points). The content was the same that I had in my education, so I had a good overview of the learning material. I taught the subject, with some interruptions, until 2003.

In 2002, as a test scheme, I introduced a folder assessment, with one test and a submission that both accounted for $20 \%$ of the final assessment. Written exam was as before, but now with a weight of $60 \%$. Folder assessment became common with the introduction of the Quality Reform in 2003-04 (Fägerlind \& Strömqvist, 2004). The engineering programs in Norway received a new framework plan at the same time, and the two courses then merged into a course of 10 credits. I have had the course responsibility for that course since 2006.

Initially, it was 6 hours of classroom teaching every week, and with laboratory exercises that the students carried out on their own, but with access to guidance. There was a fixed schedule every week, for 14-15 weeks. It is not a very flexible arrangement, for neither students nor teachers. With the introduction of the new course in 2006, I transitioned to more problem solving than before, jointly with the students. The academic year 2013-14 I went to so-called blended learning (Picciano, Dziuban, \& Graham, 2013), where I made videos to support the review of most topics. The academic year 2017-18 was another step forward, with the transition to flipped classroom (inverted classroom). The students prepare themselves by watching videos beforehand, followed by up to 2 hours of blackboard teaching and 4 hours of self-activity with guidance every week. The videos are short cuts of $6-8$ minutes, which is a recommended length (Raths, 2014). I join the student group as a guide when they solve assignments and go through topics where I see that they have challenges. I also have made videos in theory they have had 
before in other subjects, and which is necessary in control engineering. I expect the students to have watched the videos before class. Spending time in teaching sessions on reviewing the videos is to punish those who have already watched them (Raths, 2014). Finally, the students write a reflection paper where they reflect on what they have learned in the course, and whether the expectations of themselves and others have been fulfilled. The reflection is included in the final assessment. Alternatively, they can record a video. It is important to go through the learning objectives and explain the educational program at the beginning of the course. Students want to know why they should learn this, and how relevant it is to working life. The learning objectives should be repeated throughout the semester. An expectation clearance at the start of the spring semester 2019 showed that the students will have distinct requirements, and they want to know what the expectations are.

\subsection{Flipped classroom and videos}

One way to prepare before class is to watch videos. I have prepared short videos with one single theme at a time. It is lot of research on flipped classroom and videos, and I will not repeat it here (Fyfield, Henderson, Heinrich, \& Redmond, 2019; Guo, Kim, \& Rubin, 2014). However, I checked on the use of videos in 2016 and 2017, when I made a transition from blended learning to flipped classroom. The results are shown in Table 1. In 2016 it was part of a study that investigated the differences in use of videos among engineering and nursing students (Sande, Leite, \& Kyte, 2020).

Table 1. Videos in control engineering.

\begin{tabular}{|l|l|l|}
\hline Question & $\mathbf{2 0 1 6}$ & $\mathbf{2 0 1 7}$ \\
\hline $\begin{array}{l}\text { The videos made it easier to understand } \\
\text { the subject matter. }\end{array}$ & 4,94 & 4,81 \\
\hline $\begin{array}{l}\text { The videos made me well prepared for } \\
\text { the learning sessions. }\end{array}$ & 3,68 & 3,93 \\
\hline $\begin{array}{l}\text { The model with videos and learning } \\
\text { sessions is more motivating than } \\
\text { lectures }\end{array}$ & 3,10 & 2,93 \\
\hline $\begin{array}{l}\text { The model with videos and learning } \\
\text { sessions gave me a greater learning } \\
\text { outcome than lectures. }\end{array}$ & 2,83 & 2,63 \\
\hline $\begin{array}{l}\text { The learning environment in the } \\
\text { learning sessions was good. }\end{array}$ & 4,36 & 4,50 \\
\hline $\begin{array}{l}\text { To what extent have you used the } \\
\text { videos before learning sessions. }\end{array}$ & 2,81 & 3,18 \\
\hline $\begin{array}{l}\text { To what extent have you used the } \\
\text { videos after learning sessions. }\end{array}$ & 3,29 & 4,56 \\
\hline
\end{tabular}

The questionnaire had a Likert scale: To very large degree 5, to a fairly large degree 4, to a fairly small degree 3, to a very small degree 2 and not at all 1. The number of participants in the survey were 21 in 2016 and 16 in 2017.

The students agree that videos made it easier to understand the subject matter. They also think the learning environment was good. In 2017, compared to 2016, more students watched videos after class. I still have a job to do to get flipped classroom work as intended. The Covid 19 situation and use of Zoom and Teams has given me more insight in distance learning and use of videos. My students have one clear recommendation: They want to meet on campus, and work together with other students. This is in accordance with my learning view and sociocultural learning, and together with the results in Table 1, probably means that a fully-fledged flipped classroom is not the way to go, blended learning is better.

\section{Closure}

In the old days, they built bridges with stone arching. The engineer stood under the arch when they removed the formwork, to show that he relied on the work done by himself and others. He (engineers were men of that time) knew that everyone, from those who laid the foundation to the one who placed the last stone that locked the arch, had done their job. The bridge was a result of collaboration between workers with different skills, and the engineer who people at that time believed had all the answers, was 
only one part of something bigger. These bridges are still standing today; those who built them had the necessary expertise.

Many of my ancestors in Hedmark County in Norway were wheel makers. They were not educated in mathematics and had never heard that the perimeter is $\pi$ times $d$, and that $\pi=3.14$. However, they knew that if you multiply the diameter $\mathrm{d}$ with a number slightly larger than three, the wheel would be round. The knowledge had gone from father to son for generations. The learning environment consisted of family members of three generations, with the advantages and disadvantages it could have.

\section{References}

Chickering, A. W., \& Gamson, Z. F. (1987). Seven principles for good practice in undergraduate education. AAHE bulletin, 3, 7.

Dahl, B. L., \& Lindberg-Sand, Å. (2009). Conformity or confusion? Changing higher education grading scales as a part of the Bologna Process: the cases of Denmark, Norway and Sweden. Learning and Teaching, 2(1), 39-79.

Dewey, J. (1962). The relation of theory to practice in education: Association for Student Teaching Cedar Falls, Iowa.

Dysthe, O. (1999). Ulike teoriperspektiv på kunnskap og læring. [Different theoretical perspectives on knowledge and learning]. Bedre skole, 3, 4-10.

Fägerlind, I., \& Strömqvist, G. (2004). Reforming higher education in the Nordic countries: studies of change in Denmark, Finland, Iceland, Norway and Sweden: UNESCO.

Fyfield, M., Henderson, M., Heinrich, E., \& Redmond, P. (2019). Videos in higher education: Making the most of a good thing. Australasian Journal of Educational Technology, 35(5), 1-7. doi:10.14742/ajet.5930

Gornitzka, Á. (2007). What is the use of Bologna in national reform? In Creating the European area of higher education (pp. 19-41): Springer.

Guo, P. J., Kim, J., \& Rubin, R. (2014, March). How video production affects student engagement: An empirical study of MOOC videos. Paper presented at the Proceedings of the first ACM conference on Learning@ scale conference.

Picciano, A. G., Dziuban, C. D., \& Graham, C. R. (2013). Blended learning: Research perspectives (Vol. 2): Routledge.

Raths, D. (2014). Nine video tips for a better flipped classroom. The Education Digest, 79(6), 15.

Sande, J., Leite, I., \& Kyte, L. (2020, June). Self-produced videos in flipped classroom for pre-course engineering students, engineering students and nursing students. Paper presented at the END conference.

Vygotsky, L. S. (1978). Mind in society: The development of higher mental process. In: Cambridge, MA: Harvard University Press. 